\title{
Precarious employment in Chile: psychometric properties of the Chilean version of Employment Precariousness Scale in private sector workers
}

\section{Precariedad laboral en Chile: propiedades psicométricas de la versión chilena de la Escala de Precariedad Laboral en trabajadores del sector privado}

\section{Condições de emprego no Chile: propriedades psicométricas da versão chilena da Escala de Precariedade no Emprego em trabalhadores do setor privado}

\author{
Alejandra Vives-Vergara 1,2,3,4 \\ Francisca González-López 1 \\ Orielle Solar 5 \\ Pamela Bernales-Baksai 5,6 \\ María José González 5 \\ Joan Benach 2,7
}

doi: 10.1590/0102-311X00156215

\author{
Correspondence \\ A. Vives-Vergara \\ Departamento de Salud Pública, Escuela de Medicina, Pontificia \\ Universidad Católica de Chile. \\ Diagonal Paraguay 362, 2o piso, Santiago / Santiago - \\ 8330077, Chile. \\ alejandra.vives@uc.cl \\ 1 Escuela de Medicina, Pontificia Universidad Católica de Chile \\ Santiago, Chile. \\ 2 Grupo de Investigación en Desigualdades en la Salud - \\ Employment Conditions Network (GREDS-ENCOMET), \\ Universitat Pompeu Fabra, Barcelona, España. \\ 3 Centro de Desarrollo Urbano Sustentable, Santiago, Chile. \\ 4 Centro Avanzado de Enfermedades Crónicas, Santiago, Chile. \\ 5 Programa de Trabajo, Empleo, Equidad y Salud, Facultad \\ Latinoamericana de Ciencias Sociales, Santiago, Chile. \\ 6 Department of Social es Policy Sciences, University of Bath, \\ Bath, U.K. \\ 7 Grupo de Investigación Transdisciplinar sobre Transiciones \\ Socioecológicas, Universidad Autónoma de Madrid, \\ Madrid, España.
} 4,248 private salaried workers with a formal contract from the first Chilean Employment Conditions, Work, Health and Quality of Life (ENETS) survey, applied to a nationally representative sample of the Chilean workforce in 2010. Item and scale-level statistics were performed to assess scaling properties, acceptability and reliability. The six-dimensional factor structure was examined with confirmatory factor analysis. The scale exhibited high acceptability (roughly 80\%) and reliability (Cronbach's alpha 0.83) and the factor structure was confirmed. One subscale (rights) demonstrated poorer metric properties without compromising the overall scale. The Chilean version of the Employment Precariousness Scale (EPRES-Ch) demonstrated good metric properties, pointing to its suitability for use in epidemiologic and public health research.

Occupational Health; Employment; Questionnaires 


\section{Introduction}

As extensively discussed by the Employment Conditions Network (EMCONET) of the WHO Commission on the Social Determinants of Health, employment conditions are key determinants of health, affecting working conditions, occupational health and safety standards, and general living conditions 1 .

In recent decades, the increased flexibility of labor markets has become a widespread practice in many countries. Flexible employment forms tend to represent an erosion of the employment relationship, as they are less stable, tend to be less well paid, involve more limited employment protection provisions, benefits and entitlements, as well as more individualized labor relations with limited worker control over employment and working conditions. This greater precariousness of employment relationships threatens the well-being of workers and their families, with precarious employment constituting an emergent social determinant of health 2 .

By 2010, Chile was become an upper middle-income country according to the World Bank, with lower levels of informal work than other South American countries 3 , and with what has been called an emergent labor market 4 . With $55 \%$ of the Chilean working age population occupied in the labor market, and over $70 \%$ of them in salaried employment accounts for well over 5 million people 5 .

Labor market flexibility in the country dates back to the enactment of Pinochet's 1979 Plan Laboral, which, among other things, involved strict limits on collective bargaining and collective action. Although reforms to achieve greater equity via re-establishing some individual and collective rights were introduced in the 1990s, high labor flexibility was preserved 6. Between 1998 and 2006 nonpermanent employment in formal private enterprises grew from $18.8 \%$ to $30 \% 7$. To date, temporary employment continues to represent $30 \%$ of all employment 5 . On the other hand, there is also a flexible use of permanent employment: data from 2008 showed that $20 \%$ of permanent contracts were terminated during the first year, and 50\% lasted 3 years or less 7 . This, in addition to a high proportion of subcontracted and temporary agency jobs (17\% by 2013) and a high proportion of part-time employment (20\%), of which over $50 \%$ is involuntary 5.

Precariousness of employment is not new. In fact, it characterizes many jobs over the history of capitalism and, for several periods, has represented the norm rather than the exception 8 . In industrialized countries, renewed interest in employment precariousness emerged after, and in contrast with, an era of consolidation of the salaried condition 9 , as a deviation from the high levels of security and social protection which had come to be seen as the "norm" in the years that followed the Second World War. In Latin America employment relationships never actually achieved the high standards observed in more industrialized nations. But precariousness of employment will nevertheless affect all employment relations created under flexible regimes, as were established in Chile more than 30 years ago.

Despite the importance of the phenomenon, a routine, integrated indicator of precarious employment encompassing its multiple dimensions is not generally available, as it is not available in South America. Aiming to advance the understanding of the nature of precarious employment and its impact on worker's health, Amable and colleagues from GREDS-EMCONET in Spain developed the employment precariousness construct 10 based on conceptual developments by Rodgers 11 and Cano ${ }^{8}$ and qualitative research performed in Spain ${ }^{10}$. They later operationalized the construct into the multidimensional Employment Precariousness Scale (EPRES; Escala de Precariedad del Salariado in its Spanish original) for public health, occupational and social epidemiologic research 10 .

The scale encompasses six subscales corresponding to the six theoretical dimensions of the construct. These are employment instability (type and duration of the contract, length of tenure), low wages (and possible economic deprivation), limited worker rights and social protection, individualized contracts (individual level bargaining over employment conditions); worker vulnerability or defencelessness (to authoritarian, abusive or threatening treatment in the workplace), and powerlessness to exercise workplace rights. Psychometric testing and construct validation of the original EPRES were performed in Spain on a population-based sample of salaried workers who were in employment between 2004 and 2005. The questionnaire demonstrated good metric properties and the ability to assess employment precariousness among salaried employees with any type of contract, thus allowing to address the spill-over of precariousness onto permanent workers 12. Versions of the EPRES have been applied in large scale surveys in Cataluña, Spain (2010) 13, Central America (2010) 14 , and in small samples in several other countries. 
In Chile, the EPRES was included in the first Chilean Employment Conditions, Work, Health and Quality of Life Survey (ENETS), performed in 2009-2010 on a population-based sample of workers 15. Changes were introduced on the EPRES in order to perform the necessary adaptations to the Chilean labor market (e.g., income brackets), as well as following the recommendations provided by the Spanish experience 12, involving either the exclusion of items, changes in the number of response categories, the content of response scales, or the wording of items. The most significant changes affected the "rights" subscale, where ENETS developers reformulated the original questions into items relating to social security rights in terms of affiliation 16 . The same procedures employed for response categorization and scale management as the original Spanish scale are used in the Chilean EPRES 12.

The purpose of this study was to perform a psychometric analysis of the Chilean Employment Precariousness Scale (EPRES-Ch), assessing item-level and scale-level statistics, including acceptability, reliability and construct validity of the EPRES-Ch among private salaried workers.

\section{Materials and methods}

\section{Subjects and study design}

Data come from the first ENETS, applied on a representative sample of the wage-earning population of the continental urban and rural workforce. Sample selection followed a multistage, stratified, random sampling procedure. Questionnaires were administered at home by trained interviewers. Fieldwork was conducted between September 2009 and October 2010. In all, 9,503 subjects who were currently working or had been working during the preceding 12 months were interviewed, with an overall response rate of $73.9 \%$. Further details about the survey are available elsewhere 15,17 .

Because the EPRES is specifically devised for employed workers with a formal contract, the sample for this study was restricted to the subsample of currently occupied dependent workers with a contract, including domestic workers. This excludes jobless workers $(n=1,146)$, employers, selfemployed and family workers $(n=2,395)$ and dependent employees without a contract $(n=1,115)$. The military $(n=96)$, and those older than 65 years of age $(n=74)$ were also excluded to grant comparability with the original Spanish psychometric study. Finally, given the skip and branching logic in the Chilean survey, public sector employees $(n=429)$ were also excluded. The final sample size is $\mathrm{n}=4,248$.

Participation in the survey was voluntary and confidential, and informed consent was obtained from each subject. Data sets are completely anonymized and publicly available. This study was approved by the Ethics Research Committee of the Pontificia Universidad Católica de Chile.

\section{Measurement instruments}

\section{- The Chilean Employment Precariousness Scale}

The original Spanish version of the EPRES has been described elsewhere 12. As indicated above, the EPRES was adapted by ENETS developers in collaboration with GREDS-EMCONET researchers, both to adapt it to the Chilean labor market context and to include some recommendations provided by the Spanish experience.

Like the Spanish version, the EPRES-Ch is a composite measurement scale comprising six dimensions: temporariness, disempowerment, vulnerability, wages, rights and exercise rights. However, the ENETS team replaced the items from rights in the original EPRES with new items. Also, although some response categories were not identical to the Spanish original, where it was feasible, we regrouped as in the Spanish scale. In all, the EPRES-Ch has 22 items, with response scales that consist of 4-point frequency scales in the "vulnerability" and "exercise rights" subscales, 4-point ordinal scales in "wages", 5-point categorical scales in "temporariness" and "disempowerment", and 3-point categorical scales in "rights". Finally, subscale scores are computed as simple averages and then transformed into a 0-4 scale and averaged into the global EPRES score, with low scores implying low precariousness and high scores indicating high precariousness 12 . 


\section{- Demographic and occupational variables}

For the sample description, the demographic and occupational variables used were sex, age, occupation, type of contract (permanent or temporary), economic activity (9 groups according to the International Standard Industrial Classification of All Economic Activities - ISIC Rev. 4) and occupation (coded according to the International Standard Classification of Occupations - ISCO-88).

\section{$\underline{\text { Analysis }}$}

Item-level descriptive statistics were performed, including item means and standard deviations, and response value frequencies. The latter were examined to determine the extent of missing data and whether all response choices were used for the different items, as well as their endorsement frequency 18,19 .

A correlation matrix was used to examine item internal consistency and item discriminant validity using Pearson correlations after correction for overlap, i.e., excluding the item in question from the corresponding subscale 18 .

Scale-level statistics were assessed: acceptability (measured as the proportion of subjects with at least one missing item for each subscale), subscale means (with standard deviations), observed score range, proportion of subjects with lowest and highest possible scores (floor and ceiling effects, respectively), as well as Cronbach's alpha coefficient. Exploratory factor analysis was performed using principal axis analysis and varimax rotation.

Finally, the factor structure was examined with confirmatory factor analysis (CFA) 20. The EPRES is a reflective measurement model. The hypothesized model was that which resulted from the theoretical developments and exploratory factor analysis conducted with Spanish data 12. Asymptotic free distribution estimation methods were used in order to fit the non-normally distributed data. A single step, 6-factor measurement model was specified, allowing the factors to correlate freely at the latent level, and including error terms for each measured variable. Model fit was evaluated using non-normed Fit Index (NNFI) 21, Comparative Fit Index (CFI) 22, the Root Mean Square Error of Approximation (RMSEA) 23 and Standardized Root Mean Square Residual (SRMR) 24. Cut-off values indicating a good model fit were set at 0.9 for NNFI 21 and CFI 22, 0.05 for RMSEA 25 and 0.08 for SRMR 25

All analyses were performed considering the sample corresponding to a complex sample design and using SPSS for Windows, version 19.0 (IBM Corp., Armonk, USA), with the exception of CFA which was performed with R, lavaan package (https://cran.r-project.org/web/packages/lavaan/ index.html).

\section{Results}

Demographic and occupational characteristics of study participants are presented in Table 1 . The sample included a higher proportion of men (66.1\%) than women (33.9\%), with close to 50\% of the sample aged between 25 and 44, and with secondary-level education. The majority of people in the sample work in social community services and other service sector activities, and are in non-qualified manual (elementary) and non-manual (service) occupations, holding permanent contracts (81.2\%), and reporting job tenures of 3 years or less (46.4\%), with the second largest group reporting long job tenures (10 years or more) (26.2\%).

Table 2 shows item descriptive statistics. There was a low proportion of missing item-level data (below 10\%) and all response categories were used for all items, with response distributions generally skewed towards the lower end of the continuum. Endorsement of response categories was under 0.80 for all items, except two in the "temporariness" subscale (previous unemployment and tenure) and one in the "rights" subscale (active contributions to pensions system). Item means were roughly equivalent within subscales, with the exception of "job tenure" in Temporariness and "day off" in Exercise Rights, which had a higher mean than other items in that subscale, and "cover basic needs" in Wages, "active contributions to pensions system" in Rights, and "treated in an authoritarian and violent manner" in Vulnerability, which had lower means than other items in their respective subscales. 
Table 1

Demographic and occupational characteristics of the study sample. Chile, 2009-2010.

\begin{tabular}{|c|c|}
\hline Variable & $\%$ \\
\hline \multicolumn{2}{|l|}{ Age group (years) } \\
\hline $15-24$ & 14.7 \\
\hline $25-44$ & 49.5 \\
\hline $45-65$ & 35.8 \\
\hline \multicolumn{2}{|l|}{ Sex } \\
\hline Male & 66.1 \\
\hline Female & 33.9 \\
\hline \multicolumn{2}{|l|}{ Educational achievement (complete or incomplete) } \\
\hline Primary & 19.4 \\
\hline Secondary & 53.5 \\
\hline Technical & 14.2 \\
\hline University & 13.0 \\
\hline \multicolumn{2}{|l|}{ Occupation (ISCO-88) } \\
\hline Legislators, senior officials and managers & 1.2 \\
\hline Professionals & 6.8 \\
\hline Technicians and associate professionals & 10.3 \\
\hline Clerks & 12.5 \\
\hline Service workers and shop and market sales workers & 17.9 \\
\hline Skilled agricultural and fishery workers & 4.1 \\
\hline Craft and related trades workers & 14.2 \\
\hline Plant and machine operators and assemblers & 12.2 \\
\hline Elementary occupations & 20.5 \\
\hline \multicolumn{2}{|l|}{ Economic activity (ISIC Rev.4) } \\
\hline Agriculture, hunting and forestry & 12.3 \\
\hline Mining and quarrying & 3.6 \\
\hline Manufacturing & 13.4 \\
\hline Electricity, gas and water supply & 1.2 \\
\hline Construction & 10.2 \\
\hline Wholesale, hotels \& restaurants & 20.8 \\
\hline Transport, storage and communication & 8.3 \\
\hline Real estate, renting and business activities & 2.2 \\
\hline Other social community services & 28.0 \\
\hline \multicolumn{2}{|l|}{ Type of contract } \\
\hline Temporary & 18.8 \\
\hline Permanent & 81.2 \\
\hline \multicolumn{2}{|l|}{ Job tenure } \\
\hline 10 years or more & 26.2 \\
\hline $5-10$ years & 14.3 \\
\hline 3-5 years & 13.1 \\
\hline 6 months-3 years & 34.2 \\
\hline$<6$ months & 12.2 \\
\hline
\end{tabular}

ISCO-88: International Standard Classification of Occupations; ISIC Rev.4: International Standard Industrial Classification of All Economic Activities. 
Table 2

Item descriptive statistics and Pearson item-subscale correlations corrected for overlap. Chile, 2009-2010.

\begin{tabular}{|c|c|c|c|c|c|c|c|c|c|c|c|c|c|c|}
\hline \multirow[t]{2}{*}{ Item } & \multirow{2}{*}{$\begin{array}{l}\text { Missing } \\
(\%)\end{array}$} & \multirow[t]{2}{*}{ Mean } & \multirow[t]{2}{*}{ SD } & \multicolumn{5}{|c|}{ Response values frequency (\%) } & \multicolumn{6}{|c|}{ Pearson item-subscale correlations * } \\
\hline & & & & 0 & 1 & 2 & 3 & 4 & $\mathbf{T}$ & D & $\mathbf{v}$ & w & $\mathbf{R}$ & ER \\
\hline \multicolumn{15}{|l|}{ Temporariness } \\
\hline Duration of current contract & 1.1 & 0.38 & 0.89 & 80.9 & 5.2 & 8.6 & 2.2 & 2.0 & 0.42 & 0.13 & 0.12 & 0.18 & 0.12 & 0.18 \\
\hline Tenure & 0.0 & 1.92 & 1.42 & 26.2 & 14.3 & 13.1 & 34.2 & 12.2 & 0.48 & 0.15 & 0.11 & 0.16 & 0.10 & 0.17 \\
\hline $\begin{array}{l}\text { Months unemployed in } \\
\text { previous year }\end{array}$ & 0.0 & 0.31 & 0.83 & 84.4 & 6.0 & 5.2 & 2.6 & 1.8 & 0.47 & 0.15 & 0.10 & 0.13 & 0.15 & 0.13 \\
\hline \multicolumn{15}{|l|}{ Disempowerment } \\
\hline \multicolumn{15}{|l|}{ How did you settle... } \\
\hline ...your wages or salary & 7.0 & 2.21 & 1.26 & 14.6 & 15.8 & 4.5 & 51.4 & 6.6 & 0.16 & 0.82 & 0.17 & 0.27 & 0.28 & 0.11 \\
\hline ...your workplace schedule? & 5.9 & 2.25 & 1.23 & 12.1 & 19.3 & 2.0 & 54.2 & 6.5 & 0.19 & 0.87 & 0.14 & 0.22 & 0.2 & 0.07 \\
\hline ...your weekly working hours? & 6.1 & 2.32 & 1.21 & 11.2 & 17.5 & 2.5 & 55.3 & 7.4 & 0.19 & 0.85 & 0.17 & 0.22 & 0.26 & 0.11 \\
\hline \multicolumn{15}{|l|}{ Vulnerability } \\
\hline $\begin{array}{l}\text { Afraid to demand better working } \\
\text { conditions }\end{array}$ & 0.5 & 0.72 & 1.00 & 58.7 & 19.5 & 12.1 & 9.3 & - & 0.10 & 0.17 & 0.71 & 0.25 & 0.13 & 0.25 \\
\hline $\begin{array}{l}\text { Defenceless towards unfair } \\
\text { treatment }\end{array}$ & 0.4 & 0.65 & 0.99 & 62.5 & 18.7 & 8.9 & 9.6 & - & 0.10 & 0.12 & 0.73 & 0.24 & 0.11 & 0.26 \\
\hline $\begin{array}{l}\text { Afraid of being fired for } \\
\text { not doing... }\end{array}$ & 0.5 & 0.81 & 1.08 & 56.0 & 19.2 & 11.4 & 12.9 & - & 0.15 & 0.17 & 0.73 & 0.26 & 0.12 & 0.25 \\
\hline $\begin{array}{l}\text { Treated in an authoritarian and } \\
\text { violent manner }\end{array}$ & 0.3 & 0.39 & 0.78 & 74.8 & 15.0 & 5.8 & 4.1 & - & 0.06 & 0.12 & 0.63 & 0.19 & 0.11 & 0.24 \\
\hline \multicolumn{14}{|l|}{ Wages } & 0.26 \\
\hline $\begin{array}{l}\text { Monthly take home (net) wage } \\
\text { or salary }\end{array}$ & 3.4 & 2.01 & 0.87 & 6.1 & 17.9 & 41.3 & 31.3 & - & 0.22 & 0.27 & 0.17 & 0.46 & 0.30 & 0.09 \\
\hline Cover basic needs? & 0.2 & 1.01 & 0.93 & 34.3 & 39.2 & 17.5 & 8.8 & - & 0.15 & 0.21 & 0.30 & 0.69 & 0.19 & 0.17 \\
\hline Allow for unexpected expenses? & 0.4 & 1.72 & 1.06 & 16.3 & 25.8 & 27.5 & 30.1 & - & 0.14 & 0.21 & 0.28 & 0.67 & 0.20 & 0.16 \\
\hline \multicolumn{15}{|l|}{ Rights } \\
\hline Pension (active contributions) & 0.0 & 0.09 & 0.33 & 92.6 & 6.0 & 1.4 & - & - & 0.14 & 0.09 & 0.09 & 0.12 & 0.23 & 0.07 \\
\hline Unemployment insurance & 0.0 & 0.43 & 0.70 & 69.6 & 17.9 & 12.6 & - & - & 0.04 & 0.18 & 0.10 & 0.20 & 0.32 & 0.08 \\
\hline $\begin{array}{l}\text { Occupational health and safety } \\
\text { insurance }\end{array}$ & 0.4 & 0.53 & 0.75 & 62.1 & 21.7 & 15.8 & - & - & 0.17 & 0.27 & 0.09 & 0.23 & 0.31 & 0.13 \\
\hline \multicolumn{15}{|l|}{ Exercise rights } \\
\hline Weekly holidays & 1.3 & 0.98 & 1.16 & 50.7 & 16.8 & 13.9 & 17.2 & - & 0.06 & 0.02 & 0.13 & 0.010 & 0.04 & 0.51 \\
\hline Sick leave & 2.6 & 0.87 & 1.13 & 54.9 & 14.4 & 13.8 & 14.2 & - & 0.17 & 0.12 & 0.27 & 0.18 & 0.13 & 0.74 \\
\hline Go to the doctor & 2.2 & 0.81 & 1.06 & 55.0 & 17.1 & 14.7 & 11.0 & - & 0.15 & 0.07 & 0.26 & 0.14 & 0.11 & 0.73 \\
\hline Holiday & 4.7 & 0.78 & 1.09 & 56.9 & 15.3 & 10.4 & 12.7 & - & 0.23 & 0.10 & 0.24 & 0.16 & 0.13 & 0.64 \\
\hline $\begin{array}{l}\text { Day off for family or personal } \\
\text { reasons }\end{array}$ & 2.3 & 1.19 & 1.17 & 40.9 & 15.4 & 22.8 & 18.5 & - & 0.14 & 0.11 & 0.29 & 0.16 & 0.13 & 0.61 \\
\hline
\end{tabular}

SD: standard deviation.

* Item-subscale correlations with the corresponding subscale are corrected for overlap and bolded in the table.

Item-scale correlations between an item and its corresponding subscale corrected for overlap were above 0.4 for items in five subscales and above 0.2 for the Rights subscale. In addition, all 22 items correlated higher with their corresponding subscale than with the other subscales. Correlations between items and their hypothesized subscales were roughly equivalent within subscales, with a few exceptions, most notably the "monthly salary" item in Wages.

Scale-level descriptive statistics are shown in Table 3. The proportion of subjects with incomplete data ranged between $0.4 \%$ and $8.8 \%$ across subscales, the highest being for disempowerment. Globally, almost $80 \%$ of the sample responded to all items in the questionnaire. Subscale scores ranged within the theoretical 0-4 range, and the overall score ranged from 0 to 3.5. Subscale means ranged between 0.70 and 2.25 , and standard deviations are all around 1 . 
Table 3

Scale descriptive statistics: range, mean, standard deviation (SD), floor and ceiling effects, and Cronbach's alpha coefficient. Chile, $2009-2010$.

\begin{tabular}{|c|c|c|c|c|c|c|c|c|}
\hline & Items & Mean & SD & Missing items * $(\%)$ & $\begin{array}{c}\text { Observed } \\
\text { range }\end{array}$ & Floor ** (\%) & $\begin{array}{c}\text { Ceiling ** } \\
(\%)\end{array}$ & $\begin{array}{c}\text { Cronbach's } \\
\text { alpha }\end{array}$ \\
\hline Temporariness & 3 & 0.87 & 0.81 & 1.1 & $0-4$ & 24.2 & 0.0 & 0.619 \\
\hline Disempowerment & 3 & 2.25 & 1.15 & 8.8 & $0-4$ & 9.1 & 4.8 & 0.924 \\
\hline Vulnerability & 5 & 0.89 & 1.06 & 1.6 & $0-4$ & 36.1 & 1.8 & 0.867 \\
\hline Wages & 3 & 2.13 & 1.05 & 3.7 & $0-4$ & 3.5 & 5.4 & 0.762 \\
\hline Rights & 3 & 0.70 & 0.86 & 0.4 & $0-4$ & 48.6 & 0.6 & 0.436 \\
\hline Exercise rights & 5 & 1.25 & 1.17 & 8.3 & $0-4$ & 22.8 & 4.1 & 0.838 \\
\hline EPRES-Ch & 22 & 1.32 & 0.59 & 20.2 & $0-3.5$ & 0.2 & 0.0 & 0.833 \\
\hline
\end{tabular}

EPRES-Ch: Chilean Employment Precariousness Scale.

* Proportion of participants with any item missing in the scale;

** Proportion of participants with lowest (floor) and highest (ceiling) EPRES-Ch scores.

Percentages of ceiling effects were low (<5\%), but high floor effects were observed in Rights (49\%), Vulnerability (36\%) and moderately high for Exercise Rights (23\%) and Temporariness (24\%). The global score had neither significant floor nor ceiling effects. Cronbach's alpha coefficients were greater than 0.70 for four subscales, but were lower for Temporariness (0.62) and for Rights (0.44). The global Cronbach's alpha was 0.83 .

Results for the exploratory factor analysis are shown in Table 4. All items presented the highest loading within their theoretical subscale; all item loadings were above 0.35 . The model explained $52.2 \%$ of cumulative variance.

Figure 1 shows the path diagram for the first-order EPRES model. The underlying factors or dimensions, represented by ovals, are assumed to contribute to each set of items linked to them (measured variables, represented by rectangles). Double-headed arrows connecting the ellipses represent the correlations allowed among the underlying factors (factors allowed to correlate at the latent level). Fit indices indicated good fit in terms of NNFI (0.933), CFI (0.956), RMSEA (0.02) and SRMR (0.036). Chi-square was 1879.183 (p-value < 0.001). Item loadings are generally high, except for items $\mathrm{r} 1$ and r2 in Rights (0.30; 0.45, respectively).

\section{Discussion}

Chile is the first country in South America where a version of the Employment Precariousness Scale has been applied and psychometrically evaluated, and this is the first study to include confirmatory factor analysis of the EPRES. Examined on a nationally representative sample of private employees comprising a wide range of occupations and economic activities, and holding both temporary and permanent contracts, the EPRES-Ch demonstrated good acceptability, adequate metric properties and its factor structure was confirmed.

Items generally performed well, with a response rate of over $90 \%$. Interestingly, the "monthly salary" item has a high response rate (96\%). There was full use of response ranges and frequencies of endorsement of response categories below $80 \%$ as recommended 19 . The two items that had endorsements over $80 \%$ in one response category, represent, in the remaining categories unlikely situations for the sample under study: duration of current contract, with most being permanent contracts; reporting unemployment in the past year, given the high employment rate of the period; and lack of effective active contributions to the pensions system, given this is a subsample of formally employed workers. It is expected that with other samples or under different labor market conditions, these items will perform better in this regard. 
Exploratory factor analysis of the Chilean Employment Precariousness Scale (EPRES-Ch). Chile, 2009-2010.

\begin{tabular}{|c|c|c|c|c|c|c|}
\hline & \multicolumn{6}{|c|}{ Factor } \\
\hline & 1 & 2 & 3 & 4 & 5 & 6 \\
\hline \multicolumn{7}{|l|}{ Temporariness } \\
\hline Duration of current contract & & 0.11 & & & 0.50 & \\
\hline Tenure & & 0.12 & & & 0.64 & \\
\hline Months unemployed in previous year & & & & & 0.56 & 0.13 \\
\hline \multicolumn{7}{|l|}{ Disempowerment } \\
\hline \multicolumn{7}{|l|}{ How did you settle... } \\
\hline ...your wages or salary & & & 0.83 & 0.13 & & 0.17 \\
\hline ...your workplace schedule? & & & 0.92 & 0.11 & & \\
\hline ...your weekly working hours? & & & 0.89 & & 0.10 & 0.12 \\
\hline \multicolumn{7}{|l|}{ Vulnerability } \\
\hline Afraid to demand better working conditions & 0.73 & 0.12 & & & & \\
\hline Defenceless towards unfair treatment & 0.75 & 0.14 & & & & \\
\hline Afraid of being fired for not doing... & 0.75 & 0.11 & & & 0.12 & \\
\hline Treated in an authoritarian and violent manner & 0.67 & 0.14 & & & & \\
\hline Made to feel easily replaceable & 0.71 & 0.14 & & 0.13 & & \\
\hline \multicolumn{7}{|l|}{ Wages } \\
\hline Monthly take home (net) wage or salary & & & 0.17 & 0.44 & 0.20 & 0.27 \\
\hline Cover basic needs? & 0.18 & & & 0.81 & & \\
\hline Allow for unexpected expenses? & 0.15 & & & 0.79 & & 0.11 \\
\hline \multicolumn{7}{|l|}{ Rights } \\
\hline Pension (active contributions) & & & & & 0.14 & 0.36 \\
\hline Unemployment insurance & & & & 0.11 & & 0.50 \\
\hline Occupational health and safety insurance & & & 0.17 & 0.16 & 0.15 & 0.51 \\
\hline \multicolumn{7}{|l|}{ Exercise rights } \\
\hline Weekly holidays & & 0.58 & & & & \\
\hline Sick leave & 0.13 & 0.80 & & & 0.13 & \\
\hline Go to the doctor & 0.12 & 0.81 & & & & \\
\hline Holiday & 0.12 & 0.68 & & & 0.17 & \\
\hline Day off for family or personal reasons & 0.19 & 0.65 & & & & \\
\hline
\end{tabular}

Note: cumulative variance explained by the EPRES-Ch model: $52.2 \%$. Loadings $<0.1$ are not presented. The loading weights of the factor corresponding to the domain assigned by the EPRES developers are bolded.

Item means and standard deviations were roughly equivalent within scales, with few exceptions. Three items representing rather extreme or infrequent situations exhibited low means: being treated in an authoritarian or violent manner, wages not allowing covering basic needs, and having no effective active contributions to pensions. These items may serve the purpose of extending the measurement range towards more extreme situations. However, the first is a double-barreled question and would benefit from re-phrasing, as has been done successfully in the revised version of the Spanish EPRES scale 26. Conversely, "job tenure" exhibited a high mean relative to the Temporariness subscale, capturing a frequent situation in the country (short job tenures or high job rotation) 27.

Item internal consistency or the extent to which items are related to the concept being measured (item-subscale correlations) were all above the expected threshold of 0.4018 , except for items in the "rights" subscale. They did, however, satisfy the 0.2 threshold suggested by Streiner \& Norman 19. Additionally, item discriminant validity was highly satisfactory, meaning items are not measuring other concepts they are not supposed to measure. Item-scale correlations were roughly equivalent within subscales, with the exception of "monthly salary", possibly due to its more quantitative nature in contrast to the other two items in Wages. 


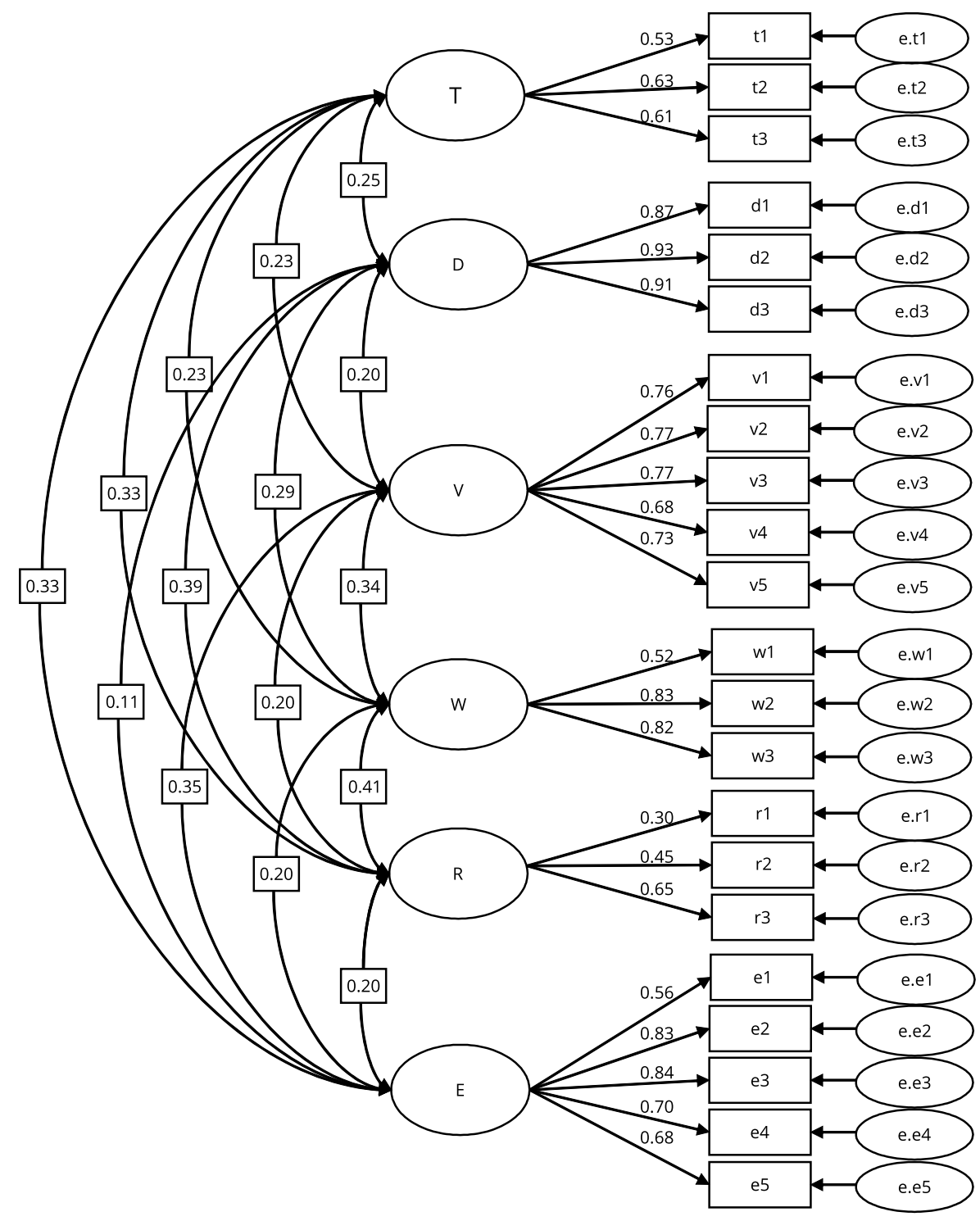

Subscales exhibited response rates at or above $90 \%$, with scores spread widely across the theoretical 0-4 score range. For the overall score, a high level of data completion indicated good acceptability, with global EPRES-Ch scores spread widely across the theoretical range and negligible floor and ceiling effects. However, high floor effects were observed for Rights (48.6\%) and Vulnerability (36\%). In the case of Rights, this is possibly due to the universal and strongly normative character of the rights being assessed, which constitute different components of social security that are mandatory in Chile. In the case of the vulnerability subscale, and as was previously discussed for the Spanish EPRES 12, this high floor effect is possibly the consequence of using double-barreled questions tapping rather extreme situations such as having received "authoritarian or violent treatment", or of favorable labor 
market conditions during the year the survey was conducted, with unemployment rates falling steadily throughout the period from $9 \%$ to $7.1 \%$. As discussed previously, this may be limiting the ability of the EPRES to identify workers with mild vulnerability, which is why rewriting double-barreled questions has being strongly recommended 12 , and successfully performed in the revised version of the Spanish EPRES 26.

Temporariness had a moderately high floor effect (24\%), although substantially lower than if the original Spanish version of the questionnaire was used (74\%). This is due to the introduction of items tapping "tenure" and "previous unemployment", which allow temporariness to better capture varying levels of stability among workers holding similar types of contracts, and especially to capture differing levels of job stability among permanent workers 12 . Exercise Rights, a subscale almost identical to the Spanish original version, had a floor effect of $22.8 \%$, which, as in Spain, is probably attributable to the universal character of most rights assessed.

The global score's Cronbach's alpha coefficient was well above 0.7, the standard considered adequate for group comparisons, indicating good reliability. However, not all scales performed similarly. While the Temporariness subscale's reliability score was close to that threshold (0.62), the Rights subscale performed poorly (0.44). This poor performance is consistent with low item-scale correlations within this subscale and the low loadings in the exploratory and confirmatory factor analyses, especially for the "active contributions to pensions system" item. This scale is also the subscale that holds least resemblance with the original EPRES.

In all, the rights subscale appeared somewhat problematic, although not as problematic as to exclude those items from the EPRES-Ch. The wording of items in rights is different to the original scale, since they are not directly assessing entitlement to the right, but rather whether workers are registered to different components of the social protection system (unemployment, pensions, and occupational health insurance). In the case of the "pensions" item, workers are asked both about enrolment and whether they are being deducted the money for their pension fund from their salary every month (which may or may not result in full entitlement to a pension by the end of his or her working life). When studying a formally employed population, these appear to be non-discriminant items. In fact, the "active contributions to pensions system" items should be better suited as an indicator of formal/informal employment. In the case of the "unemployment benefit" item, the system being assessed is mainly based on savings in individual accounts with small complements from an insurance fund 28 which until 2009 provided very restricted access. Thus, this right is also markedly different from the nature of rights assessed by the original Spanish questionnaire, which were universal and collective rights. Comparability with other versions of the EPRES scale currently under development and with the Spanish original version would benefit from the inclusion of rights of a similar nature to those assessed by the original version of the EPRES, leaving issues of registration and effective active contributions to assess the formality or informality of jobs.

The study has some limitations. One is the exclusion of public sector employees. In Chile, private sector employees are hired under a different labor code (the Chilean Labor Code) to public sector employees, most of whom are hired under the Administrative Statute. For this reason, the ENETS survey did apply a few non-identical EPRES items to public sector employees, which is why the study was restricted to private sector employees. Psychometric properties were examined among public sector employees with a more limited number of items, with similar results to those described here (results not shown). As a result, we believe the EPRES-Ch to be suitable to apply to all types of salaried workers. Own account workers and informal workers (i.e., employees working without a contract) were also excluded. The EPRES has not been fully adapted to be used in informally employed workers, but most items could be applied to them, such that a study focused on this group of workers is recommended. Regarding self-employed workers, the dimensions of precariousness are likely to differ among them when compared to dependent workers, thus requiring an in-depth study to identify and describe them. Another consideration to bear in mind is the differences between this scale and the Spanish original scale, which could compromise the equivalence between both. In fact, a revised version of the Spanish original scale has recently been published, with improvements in most scales. We recommend that future editions of the EPRES-Ch adopt these improvements which will help to overcome most problems identified here. 


\section{Conclusion}

The results of this study provide evidence of the good metric properties of the Chilean version of the EPRES, with data quality being satisfactory, scaling assumptions being met, and scale structure confirmed, suggesting the EPRES-Ch is adequate for epidemiologic research in Chile. Results also contribute to the overall assessment of the EPRES scale's psychometric properties in a different national and normative context. The study also adds new evidence of structural validity with a confirmatory factor analysis. Improvements are suggested that should be introduced for future editions of the EPRES-Ch. Employment precariousness is an emergent global social determinant of health that must be properly measured. Similar studies in other South American countries are desirable to enable international comparisons and multinational studies.

\section{Contributors}

A. Vives-Vergara designed the study, drafted the manuscript and critically revised the study and approved the final version to be published. F. González-López performed the analysis and critically revised the study and approved the final version to be published. O. Solar, P. Bernales-Baksai, and M. J. González worked in the ENETS survey development and application and in the adaptation of the EPRES and critically revised the study and approved the final version to be published.J. Benach contributed to the ENETS survey design and adaptation of EPRES and critically revised the study and approved the final version to be published.

\section{Acknowledgments}

We would particularly like to thank Marcelo Amable for very valuable discussions on the validation strategy, and Oslando Padilla (PhD) for his advice and support in the confirmatory factor analysis process. We are also grateful to the Pontificia Universidad Católica VRI/DID/104/2011, CONICYT/ FONDECYT Iniciación 11121429 (partially) for financial support. 


\section{References}

1. Benach J, Muntaner C; with the EMCONET. Employment and working conditions as health determinants. In: The Commission on Social Determinants of Health Knowledge Network, editor. Improving equity in health by addressing social determinants. Geneva: World Health Organization; 2011. p. 165-95.

2. Benach J, Vives A, Amable M, Vanroelen C, Tarafa G, Muntaner C. Precarious employment: understanding an emerging social determinant of health. Annu Rev Public Health 2014; 35:229-53.

3. Ruiz M, Tarafa G, Jódar P, Benach J. ¿Es posible comparar el empleo informal en los países de América del Sur? Análisis de su definición, clasificación y medición. Gac Sanit 2014; 29: 65-71.

4. Muntaner C, Chung H, Benach J, Ng E. Hierarchical cluster analysis of labor market regulations and population health: a taxonomy of low- and middle- income countries. BMC Public Health 2012; 12:286.

5 Instituto Nacional de Estadísticas - Chile. Nueva encuesta nacional de empleo (NENE). http://www.ine.cl (accedido el 10/Ene/2016).

6. Campero G. Macroeconomic reforms, labor markets and labor policies: Chile, 1973-2000. Geneva: International Labour Office; 2004. (Employment Strategy Papers, 2004/2).

7. Dirección del Trabajo. ENCLA 2008. Informe de resultados. Sexta encuesta laboral. Santiago: Dirección del Trabajo; 2009.

8. Cano E. Formas, percepciones y consecuencias de la precariedad. Mientras Tanto 2004; 93: 67-81.

9. Standing G. Global labour flexibility. Seeking distributive justice. v. 1. London: MacMillan Press; 1999.

10. Amable M, Benach J, González S. La precariedad laboral y su repercusión sobre la salud: conceptos y resultados preliminares de un estudio multimétodos. Arch Prev Riesgos Labor 2001; 4:169-84.

11. Rodgers G. El debate sobre el trabajo precario en Europa Occidental. In: Rodgers G, Rodgers J, editores. El trabajo precario en la regulación del mercado laboral. Crecimiento del emlpeo atípico en Europa Occidental. Madrid: Centro de Publicaciones, Ministerio del Trabajo y Seguridad Social; 1992. p. 15-41.

12. Vives A, Amable M, Ferrer M, Moncada S, Llorens C, Muntaner C, et al. The Employment Precariousness Scale (EPRES): psychometric properties of a new tool for epidemiological studies among waged and salaried workers. Occup Environ Med 2010; 67:548-55.

13. Benach J, Julià M, Tarafa G, Mir J, Molinero E, Vives A. La precariedad laboral medida de forma multidimensional: distribución social y asociación con la salud en Cataluña. Gac Sanit 2015; 29:375-8.
14. Benavides FG, Wesseling C, Delclos GL, Felknor S, Pinilla J, Rodrigo F. Working conditions and health in Central America: a survey of 12024 workers in six countries. Occup Environ Med 2014; 71:459-65.

15. Ministerio de Salud; Dirección del Trabajo; Instituto de Seguridad Laboral. Primera encuesta nacional de empleo, trabajo, salud y calidad de vida de los trabajadores y trabajadoras en Chile. Informe interinstitucional, ENETS 2009-2010. Santiago: Ministerio de Salud; Dirección del Trabajo; Instituto de Seguridad Laboral; 2011.

16. Departamento de Epidemiología, Ministerio de Salud. Precariedad laboral y salud de los trabajadores y trabajadoras de Chile. Análisis epidemiológico avanzado para la Encuesta Nacional de Empleo, Trabajo, Salud y Calidad de Vida de los Trabajadores y Trabajadoras de Chile (ENETS 2009-2010). Santiago: Ministerio de Salud; 2011.

17. Solar O, Bernales P, Sembler C, Vallebuona C, Ibáñez C. Primera encuesta nacional de empleo, trabajo y salud (ENETS 2009): diseño conceptual y metodológico. Santiago: Ministerio de Salud/Dirección del Trabajo/Instituto de Seguridad Laboral; 2010.

18. Ware JE, Gandek B. Methods for testing data quality, scaling assumptions, and reliability: the IQOLA Project approach. J Clin Epidemiol 1998; 51:945-52.

19. Streiner DL, Norman GR. Health measurement scales. A practical guide to their development and use. New York: Oxford University Press; 2008.

20. Streiner DL. Building a better model: an introduction to structural equation modelling. Can J Psychiatry 2006; 51:317-24.

21. Bentler PM, Bonett D. Significance test and goodness of fit in the analysis of covariance structures. Psychol Bull 1980; 88:588-606.

22. Bentler PM. Comparative fit indexes in structural models. Psychol Bull 1990; 107:238-46.

23. Steiger J. Structural model evaluation and modification: an interval estimation approach. Multivariate Behav Res 1990; 25:173-80.

24. Jöreskog K, Sörbom D. LISREL V: analysis of linear structural relationships by maximum likelihood and least squares methods. Uppsala: University of Uppsala; 1980.

25. Hu L, Bentler PM. Cutoff criteria for fit indexes in covariance structure analysis: conventional criteria versus new alternatives. Struct Equ Modeling 1999; 6:1-55.

26. Vives A, González F, Moncada S, Llorens C, Benach J. Measuring precarious employment in times of crisis: the revised Employment Precariousness Scale (EPRES) in Spain. Gac Sanit $2015 ; 29: 379-82$.

27. Vives A, Jaramillo H. Salud laboral en Chile. Arch Prev Riesgos Labor 2010; 13:150-6.

28. Brandt N. Reducing poverty in Chile: cash transfers and better jobs. Paris: OECD Publishing; 2012. (OECD Economics Department Working Papers, 951). 


\section{Resumen}

El estudio tuvo como objetivo realizar el análisis psicométrico (aceptabilidad, confiabilidad y estructura factorial) de la versión chilena de la nueva Escala de Precariedad Laboral (EPRES). Los datos proporcionan una muestra de 4.248 trabajadores asalariados formales del sector privado, de la primera Encuesta Nacional de Condiciones de Empleo, Trabajo y Salud (ENETS) de Chile, aplicado a una muestra representativa de la fuerza de trabajo chilena en 2010. Se calcularon las estadísticas en el nivel de item y escala para evaluar la distribución de las respuestas, aceptabilidad y confiabilidad. La estructura factorial con seis dimensiones se examinó con un análisis factorial confirmatorio. La escala mostró una alta aceptabilidad (aproximadamente 80\%) y confiabilidad (alfa de Cronbach de 0,83), y la estructura factorial fue confirmada. Una sub-escala (derechos) demostró un peor desempeño, sin comprometer la escala general. La versión chilena de la Employment Precariousness Scale (EPRES-Ch) mostró buenas propiedades métricas, sugeriendo su idoneidad al uso en epidemiología y salud pública.

Salud Laboral; Empleo; Cuestionarios

\section{Resumo}

O estudo teve como objetivo realizar a análise psicométrica (aceitabilidade, confiabilidade e estrutura fatorial) da versão chilena da nova Employment Precariousness Scale (EPRES). Os dados proveem de uma amostra de 4.248 trabalhadores assalariados formais do setor privado, do primeiro Inquérito Nacional de Condições de Emprego, Trabalho e Saúde (ENETS) do Chile, aplicado a uma amostra representativa da força de trabalho chilena em 2010. Foram calculadas as estatísticas em nivel de item e escala para avaliar as propriedades de escalabilidade, aceitabilidade e confiabilidade. A estrutura fatorial com seis dimensões foi examinada com análise fatorial confirmatória. A escala mostrou alta aceitabilidade (aproximadamente 80\%) e confiabilidade (alfa de Cronbach de 0,83), e a estrutura fatorial foi confirmada. Uma sub-escala (direitos) demonstrou propriedades métricas piores, sem comprometer a escala geral. A versão chilena da Employment Precariousness Scale (EPRES-Ch) mostrou boas propriedades métricas, destacando sua adequação para uso em epidemiologia e saúde pública.

Saúde do Trabalhador; Emprego; Questionários
Submitted on $22 / \mathrm{Sep} / 2015$

Final version resubmitted on 19/Jan/2016

Approved on 02/May/2016 